\title{
Quantitative method for determining serum alkaline phosphatase isoenzyme activity I. Guanidine hydrochloride: new reagent for selectively inhibiting major serum isoenzymes of alkaline phosphatase
}

\author{
M D S SHEPHARD, M J PEAKE
}

From the Department of Biochemistry and Chemical Pathology, Flinders Medical Centre, Bedford Park, South Australia

SUMMARY The potential use of the protein denaturant guanidine hydrochloride to inhibit selectively the enzyme activity of serum alkaline phosphatase isoenzymes from liver, bone, intestine, and placenta was investigated. Inhibition of each isoenzyme was shown to be dependent on time and concentration of inhibitor. In the presence of $0.3 \mathrm{~mol} / 1(28.7 \mathrm{~g} / \mathrm{l})$ guanidine hydrochloride for 170 seconds $14 \%, 47 \%$, and $90 \%$ of the total alkaline phosphatase activity remained in samples of bone, liver, and intestinal origins, respectively. In contrast, the activity of the placental isoenzyme increased by $24 \%$. The degree of inhibition was shown to be independent of total alkaline phosphatase activity. Investigations were performed at $37^{\circ} \mathrm{C}$ using the Cobas Bio centrifugal analyser. We conclude that this reagent has several practical advantages over urea as a selective inhibitor of alkaline phosphatase isoenzymes, including a faster and more reproducible inhibition at a much lower reagent concentration.

An increase of total serum alkaline phosphatase activity (EC 3.1.3.1) is a common finding in the clinical chemistry laboratory and is usually indicative of either osteoblastic activity, hepatobiliary disease, the presence of a tumour, or pregnancy. Four major serum isoenzymes of alkaline phosphatase have been described, their tissue origins being liver, bone, intestine, and placenta. In recent years much work has focused on the development of methods to differentiate between these isoenzymes, particularly those of liver and bone, to locate the tissue source of increased alkaline phosphatase activities.

Selective inhibition by urea has been used by several workers ${ }^{1-5}$ to differentiate isoenzymes of alkaline phosphatase. A wide range of concentrations has been used to study the effect of urea, ranging from $0.5 \mathrm{~mol} / 1(30 \mathrm{~g} / \mathrm{l})^{2}$ to $4.8 \mathrm{~mol} / 1(288 \mathrm{~g} / \mathrm{l}) .^{5}$ The degree of inhibition reported for each isoenzyme, however, has varied greatly; even using the same concentration of urea, there is no consistency in published results. ${ }^{45}$ Most methods entailing urea require the use of highly concentrated urea solutions and

Accepted for publication 26 March 1986 extended inhibition times, and these factors can impair analytical performance.

We therefore investigated the suitability of guanidine hydrochloride for the selective inactivation of alkaline phosphatase isoenzymes on the basis that this protein denaturant may provide a faster and more reliable differentiation of the four main serum isoenzymes of alkaline phosphatase at lower reagent concentrations. Guanidine hydrochloride has not been previously used for this purpose. Moss ${ }^{6}$ recently stated that, "selective inactivation methods provide what is probably the best current approach to the quantitative determination of liver and bone phosphatases," and "quantitative analysis based on selective inactivation has received less attention than its potential diagnostic advantages would suggest might be appropiate." We report our investigation of a new reagent for use in such studies.

\section{Material and methods}

MEASUREMENT OF TOTAL ALKALINE PHOS PHATASE

A single vial Monotest alkaline phosphatase (AMP buffer) kit (Boehringer Mannheim, Mannheim, West 
Table 1 Reaction conditions on Cobas Bio for measuring liver and bone alkaline phosphatase isoenzyme activity

\begin{tabular}{|c|c|c|c|c|}
\hline Instrument settings & $\begin{array}{l}\text { A } \\
\text { Total } \\
\text { activity }\end{array}$ & $\begin{array}{l}\text { B } \\
\text { Inhibition } \\
\text { studies }\end{array}$ & $\begin{array}{l}\text { C } \\
\text { Urea } \\
\text { inhibition }\end{array}$ & $\begin{array}{l}\text { D } \\
\text { Guanidine } \\
\text { hydrochloride } \\
\text { inhibition }\end{array}$ \\
\hline 1 Units & $\mathrm{U} / 1$ & $\mathrm{U} / \mathbf{l}$ & $\mathrm{U} / 1$ & $\mathrm{U} / \mathbf{I}$ \\
\hline 2 Calculation factor & 2688 & 2688 & 2688 & 2688 \\
\hline 3 Standard 1 concentration & 0 & 0 & 0 & 0 \\
\hline 4 Standard 2 concentration & 0 & 0 & 0 & 0 \\
\hline 5 Standard 3 concentration & 0 & 0 & 0 & 0 \\
\hline 6 Limit & $1 \cdot 5$ & $1 \cdot 5$ & $1 \cdot 5$ & $1 \cdot 5$ \\
\hline 7 Temperature $\left({ }^{\circ} \mathrm{C}\right)$ & 37 & 37 & 37 & 37 \\
\hline 8 Type of analysis & 2 & 2 & 2 & 2 \\
\hline 9 Wavelength (nm) & $40 \overline{5}$ & 405 & $40 \overline{5}$ & 405 \\
\hline 10 Sample volume $(\mu \mathrm{l})$ & 05 & 05 & 05 & 05 \\
\hline 11 Diluent volume $(\mu \mathrm{l})$ & 30 & 30 & 30 & 30 \\
\hline 12 Reagent volume $(\mu \mathrm{l})$ & 150 & 150 & 150 & 150 \\
\hline 13 Incubation time (seconds) & 120 & 300 & 300 & 300 \\
\hline 14 Start reagent volume $(\mu \mathrm{l})$ & 0 & 0 & 0 & 0 \\
\hline is Time of first reading (seconds) & 30 & 0.5 & 250 & 170 \\
\hline 16 Time interval (seconds) & 10 & 20 & 10 & 10 \\
\hline 17 No of readings & 20 & 30 & 07 & 07 \\
\hline 18 Blanking mode & 1 & 1 & 1 & 1 \\
\hline 19 Printout mode & 1 & 3 & 2 & 2 \\
\hline
\end{tabular}

Germany; catalogue number 396494) was used to determine the total alkaline phosphatase activity in our test samples.

To each reagent vial containing $11.5 \mathrm{ml}$ of AMP buffer $(0.9 \mathrm{~mol} / 1(80.2 \mathrm{~g} / \mathrm{l}), \mathrm{pH} 10.5)$ one tablet each of disodium p-nitrophenylphosphate substrate and magnesium chloride (final concentrations $16 \mathrm{mmol} / 1$ $(3.51 \mathrm{~g} / \mathrm{l})$ and $1.0 \mathrm{mmol} / \mathrm{l}(95 \mathrm{mg} / \mathrm{l})$ respectively) was added. After prewarming this vial for five minutes at $37^{\circ} \mathrm{C}$ total activity was determined on the Cobas Bio centrifugal analyser (Roche Analytical Instruments, Nutley, New Jersey, USA) using the instrument settings shown in table 1 (column A).

\section{INHIBITION STUDIES WITH GUANIDINE} HYDROCHLORIDE

Guanidine hydrochloride (grade 1, water soluble Sigma, St Louis, Missouri, USA) was accuratelyo weighed out and dissolved in AMP buffer from thes above kit to the desired final concentration. Substratê

Fig 1 Electrophoretic patterns (from left to right) of representative bone, liver, duodenal, jejunal, and placental source material used in experimental work. Total activities of these samples were 798. $857,995,976$, and $350 U / l$, respectively. 
and magnesium chloride tablets were then added to $11.5 \mathrm{ml}$ of this reagent. This combined reagent was mixed on a stirring wheel until completely dissolved and prewarmed for a minimum of 10 minutes at $37^{\circ} \mathrm{C}$ immediately before use. The inhibitor did not change the $\mathrm{pH}$ of the reagent at the recommended concentration. Desiccated urea (Ajax Chemicals, Sydney, Australia) was similarly used for comparative purposes.

\section{SOURCES OF ALKALINE PHOSPHATASE}

\section{ISOENZYMES}

\section{Bone}

Serum from five patients, clinically and biochemically diagnosed as having Paget's disease, were used as source material for bone (B) alkaline phosphatase throughout this study. Total alkaline phosphatase activities in these sera ranged from 1500 to $3200 \mathrm{U} / 1$. Increased activities were confirmed by conventional agarose gel electrophoresis (fig 1 ) as being of bone origin. This was further supported using wheat germ studies. $^{7}$ All sera behaved identically under the experimental conditions tested.

\section{Liver}

Serum from five patients, clinically and biochemically diagnosed as having primary biliary cirrhosis $(n=3)$, primary hepatic metastases $(n=1)$, and liver damage due to hypervitaminosis $(n=1)$ were used as source material for liver alkaline phosphatase in the study. Total activities in these sera ranged from 1250 to $1500 \mathrm{U} / \mathrm{l}$. Increased activities were confirmed by conventional electrophoretic techniques as being of liver origin (fig 1). All sera behaved identically under the experimental conditions described later. Liver extracts were not used for inhibition studies because of previously reported analytical problems ${ }^{8}$ and variable results. ${ }^{9}$

\section{Intestinal}

Sections of duodenum, jejunum, and ileum were obtained at necropsy from a patient who had died from myocardial infarction: necropsy showed no evidence of liver or bone disease.

To extract the intestinal alkaline phosphatase $20 \mathrm{ml}$ of $0.9 \%$ sodium chloride was added to each section. After gentle mixing for 45 minutes the saline, into which the intestinal alkaline phosphatase had eluted, was decanted, spun at $4000 \mathrm{rpm}$ for 10 minutes, and assayed for total alkaline phosphatase on the Cobas Bio centrifugal analyser. Activities obtained for the duodenal, jejunal, and ileal fractions were 3150,2650 , and $50 \mathrm{U} / \mathrm{l}$, respectively. The duodenal and jejunal fractions were therefore chosen for subsequent experimental work. Both sources of intestinal alkaline phosphatase behaved identically under all experi- mental conditions tested; the results for the jejunal fraction only are reported here.

\section{Placental}

Human placental alkaline phosphatase $(\mathrm{P})$, in liquid form, was obtained from the Commonwealth Serum Laboratories (CSL; Parkville, Victoria, Australia). This material was stored at $-70^{\circ} \mathrm{C}$ until analysis and had a total alkaline phosphatase activity of about $60000 \mathrm{U} / \mathrm{l}$.

Agarose gel electrophoresis confirmed the absence of other isoenzyme components in the intestinal and placental samples (fig 1).

When stored at $4^{\circ} \mathrm{C}$, the total activity and isoenzyme composition of all samples described remained stable for more than three months. Dilutions in saline were prepared to give working activities for each sample of about $500 \mathrm{U} / 1$ and $1000 \mathrm{U} / \mathrm{l}$ for use in subsequent experimentation.

\section{ELECTROPHORESIS METHOD}

Agarose gels (1\%) (agarose; BDH Chemicals Ltd, Poole, England) containing 0.5\% Triton X100 (Ajax Chemicals, Sydney, Australia) in $0.06 \mathrm{~mol} / \mathrm{l}$ barbital buffer, $\mathrm{pH} 8.6(20.6 \mathrm{~g}$ sodium barbitone and $3.7 \mathrm{~g}$ barbitone; Sigma Chemicals) were prepared for electrophoresis. Sample $(2 \mu \mathrm{l})$ was applied to the gel and electrophoresed at 250 volts for 50 minutes at room temperature. After electrophoresis the gel was overlayed with a membrane that had been soaked with the chromogenic substrate 5-bromo-4-chloro-3 indoyl phosphate, p-toluidine salt (Sigma) at a final concentration of $4.6 \mathrm{mmol} / \mathrm{l}(2 \mathrm{~g} / \mathrm{l})$ in 2-amino2-methyl-1, 3-propanediol buffer $(0.4 \mathrm{~mol} / 1(35 \cdot 7 \mathrm{~g} / \mathrm{l})$, pH 10.4) containing magnesium chloride $(0.01 \mathrm{mmol} / 1(0.95 \mathrm{mg} / \mathrm{l}))$. The gel was incubated with this membrane for 45 minutes at $37^{\circ} \mathrm{C}$ to allow the bands to resolve. The membrane was then removed and the gel dried in an oven at $75^{\circ} \mathrm{C}$ for one hour.

For lectin studies samples were mixed with an equal volume of a $5 \mathrm{~g} / 1$ aqueous solution of wheat germ lectin, incubated at $37^{\circ} \mathrm{C}$ for 30 minutes, and centrifuged at $4000 \mathrm{rpm}$ for 10 minutes. The pellet was resuspended in saline and applied to the gel.

\section{Results}

SELECTIVE INACTIVATION OF BONE AND LIVER ISOENZYMES USING GUANIDINE

HYDROCHLORIDE

Most requests from clinicians for alkaline phosphatase isoenzyme determinations require differentiation between liver and bone as the origin of an increased serum enzyme activity. Therefore a major component of this study was to investigate the ability of guanidine hydrochloride to discriminate between 


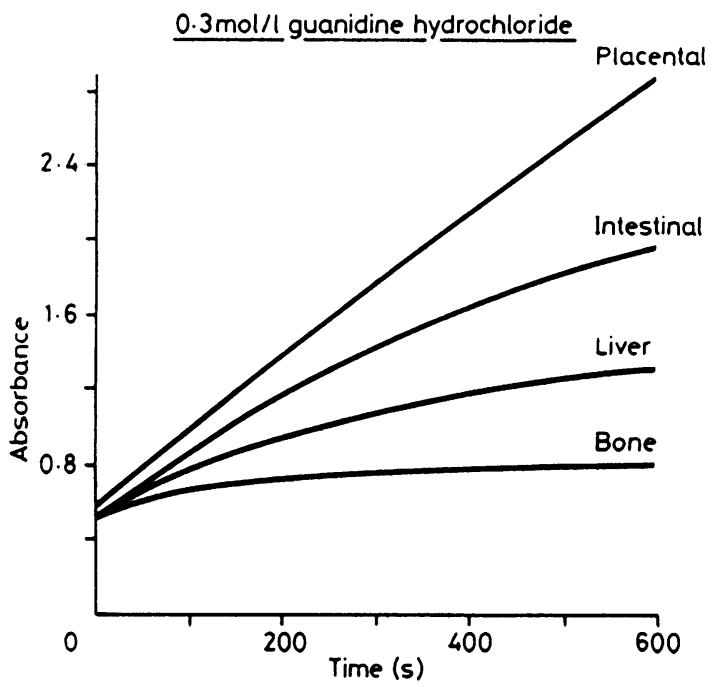

Fig 2 Inhibition of bone, liver, intestinal, and placental isoenzymes using $0.3 \mathrm{~mol} / \mathrm{l}$ guanidine hydrochloride at $37^{\circ} \mathrm{C}$. Total activities of these fractions were 490, 505, 514, and $521 \mathrm{U} / \mathrm{l}$, respectively.

these two isoenzymes.

Initially, the kinetics of the inhibition of the bone and liver alkaline phosphatase activity by guanidine hydrochloride were investigated on Cobas Bio using the instrument settings shown in table 1 (column B).

The inhibitory effects of a wide range of guanidine hydrochloride concentrations were examined; final concentrations in the reaction cuvette ranged from $0.025 \mathrm{~mol} / 1$ to $1.2 \mathrm{~mol} / \mathrm{l}$. At the extremes of these concentration ranges inhibition was found to be either too small or too great and, as a result, guanidine hydrochloride concentrations from $0 \cdot 15 \mathrm{~mol} / 1$ $(11.7 \mathrm{~g} / \mathrm{l})$ to $0.35 \mathrm{~mol} / 1(14.3 \mathrm{~g} / \mathrm{l})$ were used for detailed investigations. For comparative purposes, urea concentrations from $1.3 \mathrm{~mol} / \mathrm{l}(78 \mathrm{~g} / \mathrm{l})$ to $1.7 \mathrm{~mol} / \mathrm{l}$ $(102 \mathrm{~g} / 1)$ were similarly used.

Because exact temperature control is essential for reproducible results, the substrate containing inhibitor was preincubated at $37^{\circ} \mathrm{C}$ for five minutes in the centrifugal analyser before the sample was added. The kinetics of the inhibition of the bone and liver samples at the working concentrations indicated were found to be non-linear for both guanidine hydrochloride (fig 2) and urea.

Using the absorbance data obtained, the alkaline phosphatase activity remaining for both the liver and bone specimens at different time intervals and final concentrations of guanidine hydrochloride were calculated (table 2). The concentrations of inhibitory agent specified represent final concentrations in the reaction cuvettes.

The non-linear inhibition pattern, in combination with the pronounced changes in the percentage residual activity of liver and bone isoenzymes caused by minor differences in either time or concentration, may explain why previous workers have been unable to produce consistent results using urea as a selective inhibitor.

\section{SELECTION OF CONDITIONS FOR OPTIMAL} DISCRIMINATION BETWEEN LIVER AND BONE ISOENZYMES USING GUANIDINE

\section{HYDROCHLORIDE}

From these preliminary data, analytical conditions for further investigation were selected, based on the following criteria:

1 Residual activity of the bone isoenzyme should be sufficient to permit precise measurement and should, therefore, exceed $10 \%$ of the original total alkaline phosphatase activity.

2 Maximum absorbance must not exceed two absorbance units over the time interval during which enzyme activity is monitored.

Table 2 Activity remaining and percentage (in parentheses) of liver $(L)$ and bone $(B)$ alkaline phosphatase of original activity remaining following inhibition by guanidine hydrochloride.

\begin{tabular}{|c|c|c|c|c|c|c|c|c|}
\hline \multirow{2}{*}{$\begin{array}{l}\text { Final } \\
\text { concentration } \\
\text { of guanidine } \\
\text { hydrochloride } \\
(\text { mol/l) }\end{array}$} & & \multicolumn{7}{|c|}{ Time interval (seconds) } \\
\hline & & $10-70$ & $90-150$ & $170-230$ & $250-310$ & $330-390$ & $410-470$ & $490-550$ \\
\hline $0 \cdot 15$ & $\mathbf{L}$ & $882^{\mathrm{a}}(100)$ & $819(96)$ & $767(89)$ & $719(84)$ & $677(79)$ & $624(73)$ & $586(68)$ \\
\hline $0 \cdot 20$ & $\begin{array}{l}\mathbf{B} \\
\mathbf{L}\end{array}$ & $\begin{array}{l}804^{2}(100) \\
877(100)\end{array}$ & $\begin{array}{l}674(84) \\
776(91)\end{array}$ & $\begin{array}{l}575(72) \\
695(81)\end{array}$ & $\begin{array}{l}490(61) \\
627(73)\end{array}$ & $\begin{array}{l}424(53) \\
571(66)\end{array}$ & $\begin{array}{l}362(45) \\
513(60)\end{array}$ & $\begin{array}{l}312(39) \\
466(54)\end{array}$ \\
\hline & B & $735(92)$ & $555(70)$ & $431(54)$ & 338 (42) & 269 (34) & $215(27)$ & $174(22)$ \\
\hline 0.25 & $\begin{array}{l}\mathbf{L} \\
\mathbf{B}\end{array}$ & $825(96)$ & $671(78)$ & $562(66)$ & $478(56)$ & 409 (47) & 349 (41) & 301 (35) \\
\hline $0 \cdot 30$ & L & $\begin{array}{l}632(79) \\
716(84)\end{array}$ & $\begin{array}{l}380(48) \\
533(62)\end{array}$ & $\begin{array}{l}244(31) \\
412(47)\end{array}$ & $\begin{array}{l}163(20) \\
324(38)\end{array}$ & $\begin{array}{l}114(14) \\
259(30)\end{array}$ & $\begin{array}{r}84(11) \\
209(24)\end{array}$ & $\begin{array}{c}61(8) \\
170(20)\end{array}$ \\
\hline & B & $482(60)$ & $204(26)$ & 109 (14) & $64(8)$ & $45(6)$ & 31 (4) & $24(3)$ \\
\hline $0 \cdot 35$ & $\begin{array}{l}\text { L } \\
\text { B }\end{array}$ & $\begin{array}{l}658(77) \\
348(44)\end{array}$ & $\begin{array}{l}403(47) \\
107(13)\end{array}$ & $\begin{array}{r}277(32) \\
53(7)\end{array}$ & $\begin{array}{c}194(23) \\
30(4)\end{array}$ & $\begin{array}{c}142(17) \\
23(3)\end{array}$ & $\begin{array}{c}105(12) \\
17(2)\end{array}$ & $\begin{array}{l}79(9) \\
13(2)\end{array}$ \\
\hline
\end{tabular}

The total alkaline phosphatase activity of the liver and bone specimens used in this experiment was $857 \mathrm{U} / 1$ and $798 \mathrm{U} / \mathrm{l}$, respectively. 
3 The residual percentage activity of the liver isoenzyme must exceed that of the bone isoenzyme by a factor of 3 during the designated reading interval.

The concentrations of guanidine hydrochloride and the time intervals that satisfied the above criteria were: $0.3 \mathrm{~mol} / 1$ from $170-230$ seconds; $0.25 \mathrm{~mol} / 1$ from $330-390$ seconds; and $0.35 \mathrm{~mol} / 1$ from $90-150 \mathrm{sec}-$ onds. This last option was not chosen because of the rapid change in bone alkaline phosphatase activity over this period (fig 2). To further investigate the first two options intrarun precision studies $(n=7)$ were carried out using the liver and bone samples together with a commercial lyophilised enzyme quality control material used in our routine laboratory (Omega Assayed Chemistry Control Serum II; Hyland Diagnostics, Malvern, Pennsylvania, USA). Table 3 summarises these results.

Guanidine hydrochloride $(0.3 \mathrm{~mol} / \mathrm{l})$ was selected as the concentration of choice over a reading interval of 170-230 seconds to minimise both the possibility of abnormally high absorbance readings and to reduce analysis time.

The instrument settings finally selected for the quantitative discrimination of liver and bone alkaline phosphatase isoenzymes using guanidine hydrochloride are shown in table 1 (column D). To summarise, the reaction is carried out at $37^{\circ} \mathrm{C}$, the time of the first reading is 170 seconds using a final inhibitor concentration of $0.3 \mathrm{~mol} / \mathrm{l}$, the reaction is monitored for one minute at 10 second intervals, and the activity is automatically calculated by linear regression. For the bone isoenzyme, $14 \%$ of the total activity remained in the presence of inhibitor, while for the liver isoenzyme, $47 \%$ of the total activity remained. Optimal reaction conditions for urea were similarly determined, using the same criteria and intrarun precision studies. Final instrument settings selected for use with this reagent are shown in table 1 (column C).

INTESTINAL AND PLACENTAL ISOENZYME STUDIES WITH GUANIDINE HYDROCHLORIDE Having optimised reaction conditions and obtained maximal discrimination between the liver and bone isoenzymes using $0.3 \mathrm{~mol} / 1$ guanidine hydrochloride, intestinal and placental fractions were then tested under these final experimental conditions.
Table 4 Percentage activity remaining for each isoenzyme in the presence of $0.3 \mathrm{~mol} / \mathrm{l}$ guanidine hydrochloride*

\begin{tabular}{lll}
\hline & \multicolumn{2}{l}{ Percentage activity remaining } \\
\cline { 2 - 3 } & $\begin{array}{l}\text { Guanidine } \\
\text { hydrochloride } \\
(0 \cdot 3 \text { mol/l) } \\
\text { Time interval } \\
(170-230 \text { seconds })\end{array}$ & $\begin{array}{l}\text { Urea } \\
(1 \cdot 3 \text { mol/l) } \\
\text { Time interval } \\
(250-310 \text { seconds })\end{array}$ \\
Isoenzyme & 14 & 15 \\
\hline Bone & 47 & 50 \\
Liver & 90 & 67 \\
Intestinal & 124 & 83 \\
Placental & & \\
\hline
\end{tabular}

*For comparative purposes similar data for $1.3 \mathrm{~mol} / \mathrm{l}$ urea are also shown.

For the intestinal fraction, $90 \%$ of the total activity remained in the presence of guanidine hydrochloride, and inhibition was non-linear. In contrast, the activity of the placental isoenzyme fraction increased by $24 \%$, and activation of placental alkaline phosphatase was linear with time (fig 2). Quality assurance sera (Australian Quality Assurance General Serum Chemistry Programme, supplied by the Commonwealth Serum Laboratories), which contained over $90 \%$ placental alkaline phosphatase, displayed a similar activation of total activity in the presence of $0.3 \mathrm{~mol} / \mathrm{l}$ guanidine hydrochloride.

SUMMARY OF THE ACTION OF GUANIDINE HYDROCHLORIDE OR ALKALINE PHOSPHATASE ISOENZYMES

Table 4 summarises the inhibition or activation of each isoenzyme of alkaline phosphatase with $0.3 \mathrm{~mol} / \mathrm{l}$ guanidine hydrochloride. Table 4 shows the inhibition obtained under optimised conditions using $1.3 \mathrm{~mol} / \mathrm{l}$ urea included for comparative purposes. The pronounced differences observed between fractions with guanidine hydrochloride not only for the bone and liver isoenzymes but also for the intestinal and placental fractions corroborate the usefulness of this agent in the selective inhibition of isoenzymes of alkaline phosphatase

REPRODUCIBILITY OF ISOENZYME INHIBITION Day to day precision studies were then carried out using all four isoenzyme fractions. The results of 12

Table 3 Intrarun precision studies

\begin{tabular}{|c|c|c|c|c|}
\hline \multicolumn{2}{|l|}{ Conditions } & \multicolumn{3}{|c|}{ Intrarun precision (coefficient variation \%) } \\
\hline $\begin{array}{l}\text { Guanidine hydrochloride } \\
\text { (mol/l) }\end{array}$ & $\begin{array}{l}\text { Time interval } \\
\text { (seconds) }\end{array}$ & Liver & Bone & Commercial $Q C$ \\
\hline $\begin{array}{l}0 \cdot 3 \\
0 \cdot 25\end{array}$ & $\begin{array}{l}170-230 \\
330-390\end{array}$ & $\begin{array}{l}2 \cdot 37 \\
2 \cdot 37\end{array}$ & $\begin{array}{l}4 \cdot 00 \\
3 \cdot 13\end{array}$ & $\begin{array}{l}1 \cdot 01 \\
1.41\end{array}$ \\
\hline
\end{tabular}


Table 5 Percentage activity remaining for four isoenzymes of alkaline phosphatase in presence of guanidine hydrochloride: results of day to day precision studies

\begin{tabular}{|c|c|c|c|c|c|c|}
\hline \multirow{3}{*}{$\begin{array}{l}\text { Condition } \\
\text { Sample }\end{array}$} & \multicolumn{6}{|c|}{ Percentage activity remaining } \\
\hline & \multicolumn{4}{|c|}{$\begin{array}{l}0.3 \text { mol/l guanidine hydrochloride } \\
\text { Time interval } \\
(170-230 \text { seconds })\end{array}$} & \multicolumn{2}{|c|}{$\begin{array}{l}1 \cdot 3 \text { mol/l urea } \\
\text { Time interval } \\
(250-310 \text { seconds })\end{array}$} \\
\hline & Bone & Liver & Intestinal & Placental & Bone & Liver \\
\hline $\begin{array}{l}\text { Mean } \\
\text { SD } \\
\text { CV }(\%) \\
\text { No }\end{array}$ & $\begin{array}{l}13 \cdot 6 \\
0 \cdot 73 \\
5 \cdot 4 \\
12\end{array}$ & $\begin{array}{l}46 \cdot 6 \\
1.40 \\
2 \cdot 9 \\
12\end{array}$ & $\begin{array}{l}90 \cdot 2 \\
2 \cdot 53 \\
2 \cdot 8 \\
12\end{array}$ & $\begin{array}{c}124 \cdot 4 \\
5 \cdot 35 \\
4 \cdot 3 \\
12\end{array}$ & $\begin{array}{l}15 \cdot 3 \\
1 \cdot 16 \\
7 \cdot 4 \\
12\end{array}$ & $\begin{array}{l}50 \cdot 3 \\
1.83 \\
3 \cdot 6 \\
12\end{array}$ \\
\hline
\end{tabular}

assays (table 5) show that the method using guanidine hydrochloride is reproducible and precise. Similar data for urea using the liver and bone isoenzymes are also shown.

\section{Conclusion}

Investigation of a new selective inhibitor, guanidine hydrochloride, and its action on the four major serum isoenzymes of alkaline phosphatase, have been described. Investigations were performed at $37^{\circ} \mathrm{C}$ using the Cobas Bio centrifugal analyser. Optimal reaction conditions were determined and a precise reproducible assay suitable for use in combination with other selective inhibitors in routine diagnostic situations was developed. Simplicity was improved by the direct inclusion of guanidine hydrochloride in the alkaline phosphatase substrate.

Advantages of guanidine hydrochloride over urea as a selective inhibitor of alkaline phosphatase isoenzymes include:

\section{More potent inhibitor}

Similar inhibition is produced by guanidine hydrochloride at less than one quarter the molar concentration required for urea, thus avoiding the use of viscous and highly saturated solutions.

\section{Reduced inhibition times}

Faster inhibition allows activity measurements soon after the addition of guanidine hydrochloride and minimises the possibility of abnormally high absorbance measurements, especially when activity is measured at $37^{\circ} \mathrm{C}$. Long incubation times have previously been required with urea.

\section{Stability}

The reagent containing guanidine hydrochloride is stable for three days as opposed to one day for urea.

\section{Improved precision}

The assay using guanidine hydrochloride is more precise.

\section{Better discrimination}

This inhibitor provides for better discrimination between intestinal and placental isoenzymes.

In the following paper we will show how this new inhibitor has been coupled with other selective inhibition techniques to quantitate all four major serum alkaline phosphatase isoenzymes in patient specimens, develop age and sex related reference ranges, and show its usefulness in a variety of clinical situations.

We thank Dr G White for this interest in this project and for his constructive comments during the preparation of this manuscript.

\section{References}

1 Birkett DJ, Conyers RAJ, Neale FC, Posen S, Brudenell-Woods J. Action of urea on human alkaline phosphatases with a description of some automated techniques for the study of enzyme kinetics. Arch Biochem Biophys 1967;121:470-9.

2 Bahr M, Wilkinson JH. Urea as a selective inhibitor of human tissue alkaline phosphatases. Clin Chim Acta 1967;17:367-70.

3 Statland BE, Nishi H, Young DS. Serum alkaline phosphatase. Total activity and isoenzyme determinations made by use of the centrifugal fast analyser. Clin Chem 1972;18:1468-74.

4 O'Carroll D, Statland BE, Steele BW, Burke MD. Chemical inhibition method for alkaline phosphatase isoenzymes in human serum. Am J Clin Pathol 1975;63:564-72.

5 Buttery JE, Milner CR, Nenadovic P, Pannal PR. Detection of alkaline phosphatase/immunoglobulin complexes. Clin Chem 1980;26:1620-1.

6 Moss DW. Alkaline phosphatase isoenzymes. Clin Chem 1982;28:2007-16.

7 Rosalki SB, Foo AY. Two new methods for separating and quantifying bone and liver alkaline phosphatase isoenzymes in plasma. Clin Chem 1984;30:1182-6.

8 Walker AW, Pollard AC. Observations of serum alkaline phosphatase electrophoretic patterns on polyacrylamide gel with particular reference to the effects of butanol extraction. Clin Chim Acta 1971;34:19-29.

9 Horne M, Cornish CJ, Posen S. The use of urea denaturation in the identification of human alkaline phosphatases. $J$ Lab Clin Med 1968;72:905-15.

Requests for reprints to: Mr MDS Shephard, Department of Biochemistry and Chemical Pathology, Flinders Medical Centre, Bedford Park, South Australia 5042, Australia. 